\title{
Single Cell Gel Electrophoresis (Comet Assay) Mediated Evaluation of DNA Damage in Buccal Epithelial Cells Among Alcohol Users
}

\author{
Sarim Ahmad ${ }^{1 *}$, SS Ahmed ${ }^{2}$, Yasar Hasan Siddique ${ }^{3}$, Seema Sharma ${ }^{1}$, Smita Jyoti ${ }^{3}$ and Shamim \\ Ahmad $^{4}$
}

${ }^{1}$ Department of Oral Pathology and Microbiology, India

${ }^{2}$ Department of Oral and Maxillofacial Surgery, India

${ }^{3}$ Department of Zoology, India

${ }^{4}$ Microbiology Section, India

*Corresponding author: Sarim Ahmad, Department of Oral Pathology and Microbiology, India

\begin{abstract}
ARTICLE INFO
Received: 幽 August 20, 2019

Published: 幽 August 27, 2019

\section{ABSTRACT}

Introduction: Ethanol is the principal ingredient of alcoholic beverages and Acetaldehyde, a metabolite of ethanol plays an important role in ethanol toxicity by cross linking the DNA and thus leading to DNA damage. Comet Assay was performed to assess DNA damage among users of Alcohol.
\end{abstract}

Citation: Sarim Ahmad, SS Ahmed, Yasar Hasan Siddique, Seema Sharma, Smita Jyoti, et al., Single Cell Gel Electrophoresis(Comet Assay) Mediated Evaluation of DNA Damage in Buccal Epithelial Cells Among Alcohol Users . Biomed J Sci \& Tech Res 20(5)-2019. BJSTR. MS.ID.003524.
Method: Buccal epithelial cells were taken from 50 users of Alcohol and 25 control subjects were taken and Comet Assay was performed to assess possible DNA damage.

Result: Increase in the comet tail length implicated DNA damage in users of Alcohol as compared to the control subjects.

Conclusion: This study demonstrated DNA damage among users of Alcohol leading to the development of oral cancer.

Keywords: Comet Assay; Ethanol; Acetaldehyde; DNA Damage; Oral Cancer

\section{Introduction}

Ethanol is the principal ingredient of alcoholic beverages. Ethanol is classified as group I (human carcinogen) by International Agency for Research on Cancer (IARC). Ethanol genotoxicity can contribute to cell death [1]. DNA damage plays an important role in neurotoxicity, carcinogenicity or congenital anomalies induced by ethanol. Acetaldehyde, a metabolite of ethanol plays an important role in ethanol toxicity by cross linking the DNA and thus leading to DNA damage. Acetaldehyde has been proposed as the carcinogenic agent behind ethanol-related oral cancers [2]. Acetaldehyde is the main and primary metabolite of ethanol. It is a highly reactive compound that can react with amino groups of proteins. The interaction of acetaldehyde with DNA bases produces a variety of adducts with the most prevalent of these being N2ethyl-deoxyguanosine [3]. Chronic alcohol consumption leads to the development of cancer of the upper gastrointestinal tract, liver, colorectum and female breast [4,5]. At the hepatic level, nuclear and mitochondrial DNA strand-break formation was demonstrated $[6,7]$ as well as DNA adducts formation [8,9]. The most common assumption is that the free radical generation plays an important role in the genotoxicity of ethanol $[10,11]$. There is a balance between endogenous oxidants and antioxidants maintained under physiological conditions. The excessive generation of oxidants or a decrease of antioxidants causes an imbalance and the abnormal oxidant system then reaches to the level of oxidative stress [12]. The interaction of Reactive Oxygen Species with DNA can cause a significant DNA damage. DNA repair mechanism plays an important role in the maintenance of DNA integrity and prevention of cancer. If DNA remains unrepaired, it will lead to mutagenesis, genetic instability and ultimately cell death leading to genotoxicity and cytotoxicity and utilmately to the development of cancer. The 
assessment of DNA damage at individual cell level can be performed through the application of potential, fluorescent microscopic technique such as the Single Cell Gel Electrophoresis also known as the "COMET ASSAY". Damaged DNA appears as a tail, whereas undamaged DNA present itself in the comet head $[13,14]$. Comet tail length is measured to assess the DNA damage i.e. more the length of the tail more is the DNA damage15. Buccal epithelial cells are an alternative for lymphocytes which are withdrawn from human blood and is the least invasive method as they are collected by a gentle scraping of the lining of the cheek of the mouth and buccal mucosa is the first site of epithelial contact with alcohol. This makes a buccal cell comet assay model a very potential and effective tool for investigating in vitro and in vivo effects on DNA damage.

\section{Materials and Methods}

The study comprises of samples taken from 75 subjects (50 Alcohol users and 25 control subjects). The samples were taken from the Department of Oral and Maxillofacial Pathology \& Microbiology, Santosh Dental College, Ghaziabad and Dr. Ziauddin Ahmad Dental College \& Hospital, Aligarh Muslim University, Aligarh, UP. Complete history of oral habits was recorded from each subject before taking the sample. The samples were assessed for the extent of DNA damage using Comet Assay also known as Single Cell Gel Electrophoresis (SCGE).

\section{Materials}

a) Phosphate Buffered Saline medium (PBS)

b) Agarose Gel

c) $\quad 0.25 \%$ Trypsin Solution

Table 1: Comet tail length in males. d) $10 \%$ Dimethyl Sulfoxide (DMSO)

e) $10 \mathrm{mM}$ Trizma Hydrochloride (Tris-HCL) Base

f) M Ethylene Diamine Tetra Acetic Acid (EDTA)

g) $2.5 \mathrm{M}$ Sodium Chloride (NaCL)

h) $300 \mathrm{mM}$ Sodium Hydroxide $(\mathrm{NaOH})$

\section{Method}

Buccal epithelial cells were collected from subjects by using a soft bristle toothbrush gently from the oral mucosa. The brush was then swirled into a tube containing cold phosphate buffered Saline medium (PBS) and centrifuged at 2000rpm for $10 \mathrm{~min}$. The supernatant was removed and $300 \mu \mathrm{l}$ of trypsin solution was added to the buccal cells and incubated for $30 \mathrm{~min}$. at $37^{\circ} \mathrm{C}$. The cells were centrifuged, and the supernatant was discarded. About $40 \mu \mathrm{l}$ of cell suspension and $60 \mu \mathrm{l}$ of $0.5 \%$ Low Melting Point Agarose (LMPA) were mixed and placed on frosted slides previously coated with 1\% Normal Melting Point Agarose (NMPA). To the solidified agarose, a third layer of $1 \%$ low melting agarose was applied and the slides were dipped in freshly prepared cold lysing solution for 24 hours. The slides were subjected to electrophoresis, followed by neutralization $(0.4 \mathrm{M}$ Tris- $\mathrm{HCl})$ and stained with ethidium bromide $(20 \mu \mathrm{g} / \mathrm{ml})$. Three slides were prepared per individual and observed under a fluorescent microscope and analyzed for scoring comet tail length by using comet score 1.5 software.

\section{Results}

(Figure 1- 3 and Table 1-3).

\begin{tabular}{|c|c|c|c|}
\hline Group & N & Age (Mean \pm SE) & Comet tail length (Mean \pm SE) \\
\hline Alcohol users & 17 & $39.05 \pm 1.5$ & $23.04 \pm 0.4^{*}$ \\
\hline Controls & 9 & $34.00 \pm 2.1$ & $1.85 \pm 0.9$ \\
\hline
\end{tabular}

Note: * $p<0.05$ (Significant with respect to controls)

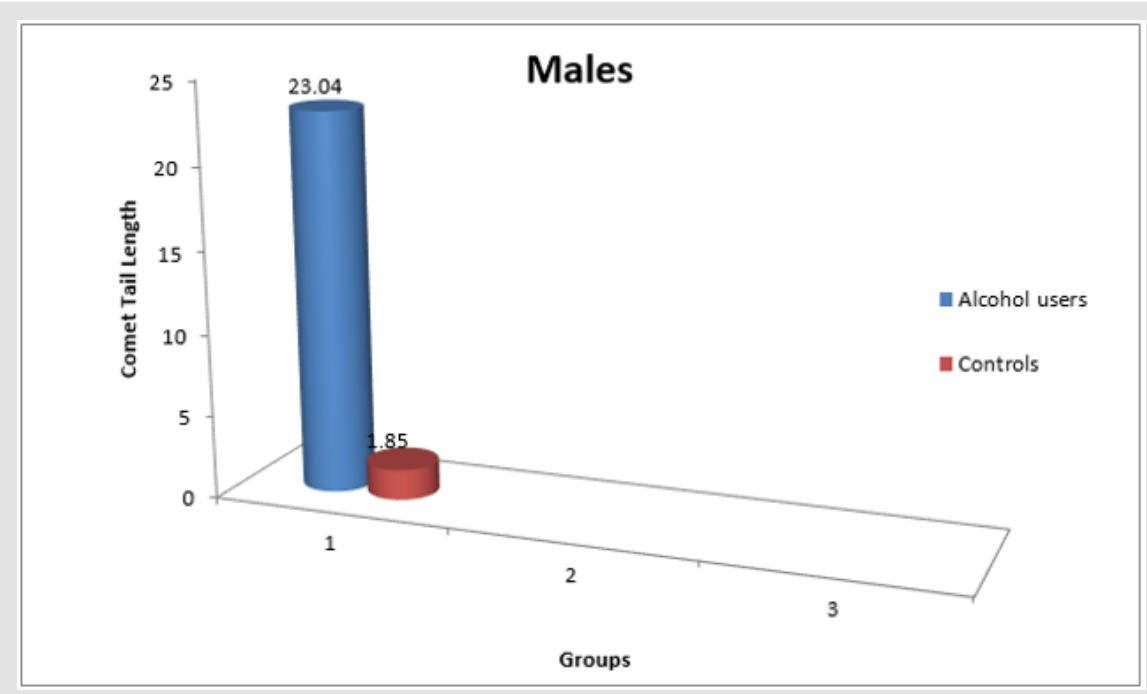

Figure 1. 


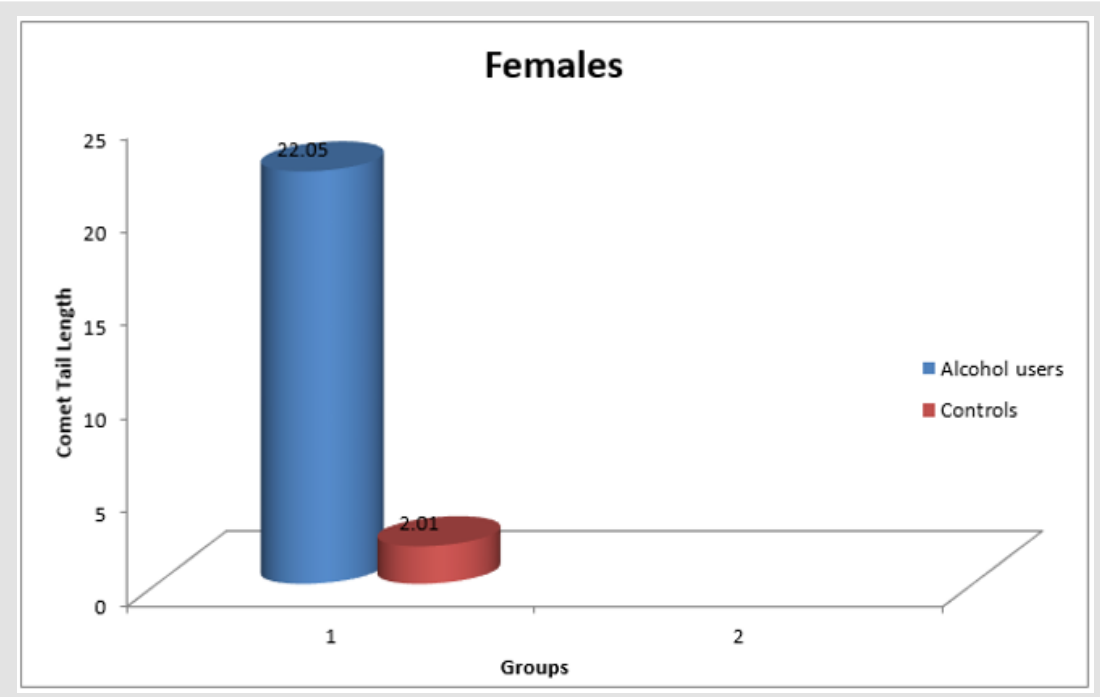

Figure 2.

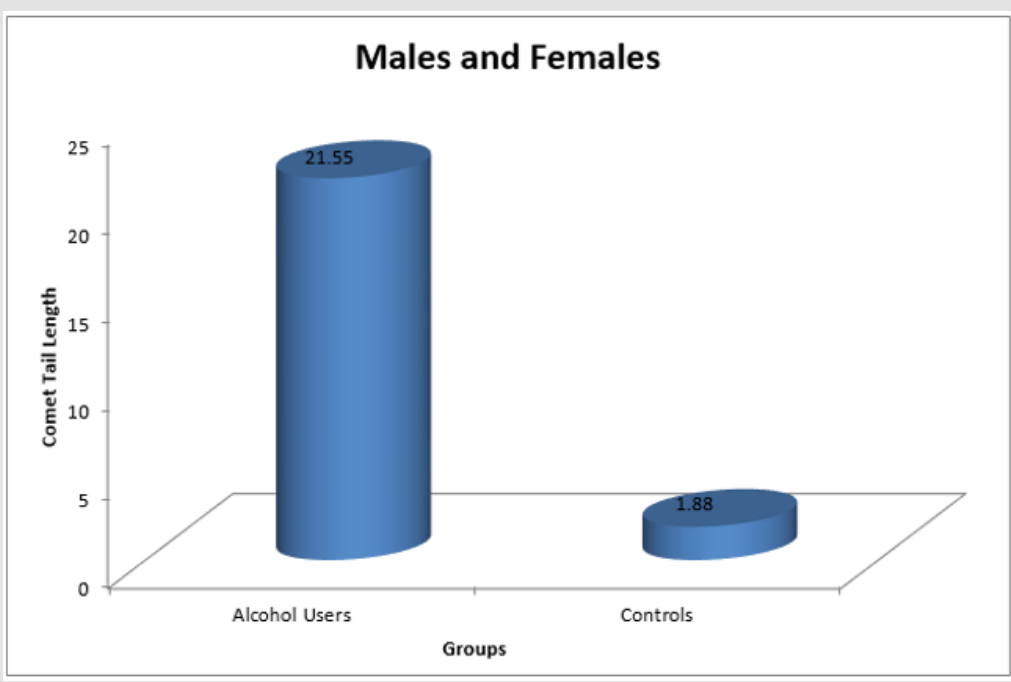

Figure 3.

Table 2: Comet tail length in females.

\begin{tabular}{|c|c|c|c|}
\hline Group & N & Age (Mean \pm SE) & Comet tail length (Mean \pm SE) \\
\hline Alcohol users & 19 & $30.50 \pm 1.8$ & $22.05 \pm 0.6^{*}$ \\
\hline Controls & 8 & $33.82 \pm 2.1$ & $2.01 \pm 0.1$ \\
\hline
\end{tabular}

Note: * $\mathrm{p}<0.05$ (Significant with respect to controls)

Table 3: Comet tail length in Males and Females combined.

\begin{tabular}{|c|c|c|c|}
\hline Group & N & Age (Mean \pm SE) & Comet tail length (Mean \pm SE) \\
\hline Alcohol users & 19 & $30.50 \pm 1.8$ & $22.05 \pm 0.6^{*}$ \\
\hline Controls & 8 & $33.82 \pm 2.1$ & $2.01 \pm 0.1$ \\
\hline
\end{tabular}

${ }^{*} \mathrm{p}<0.05$ (Significant with respect to controls)

\section{Statistical Analysis}

The present study was conducted to assess the extent of DNA damage amongst Alcohol users. Mean Comet tail length of Alcohol users was measured. Mean Comet tail length was compared between control subjects and Alcohol users using t-test to analyze the results. All statistical analyses were done using SPSS $®$ V8.2 statistical software package and Statistica Soft Inc.

\section{Discussion}

Very few studies related to the genotoxic and cytotoxic effects of Alcohol have been conducted on buccal epithelial cells. Buccal cells were collected by gentle scraping of the lining of the cheek of the mouth. This makes a buccal cell comet assay model an attractive and potentially useful tool for investigating in vitro and in vivo effects on DNA damage caused by the consumption of Alcoholic beverages 
[15-18]. The most obvious line of explanation that alcohol intake can lead to DNA damage is the positive association between alcohol intake and development of oropharyngeal cancer. Prolonged alcohol intake is positively associated with increased risk of several types of cancers, including cancer of the liver and digestive tract. The association of alcohol intake with cancer strongly suggests that in some manner prolonged alcohol consumption can result in changes in the sequence of genomic DNA [19-21]. Chronic alcohol consumption and metabolism result in the generation of several classes of DNA damaging molecules, including reactive oxygen species (ROS), lipid peroxidation products, and acetaldehyde $[22,23]$. Blasiak et al. [11] studied the influence of ethanol and acetaldehyde on DNA in human lymphocytes, gastric mucosa and colonic mucosa by Comet Assay and deduced that colonic mucosa cells showed the highest sensitivity of all cell types to ethanol than lymphocytes and gastric mucosa cells [22]. There were no differences in the sensitivity to acetaldehyde of all the cell types. This clearly indicated that ethanol and acetaldehyde can contribute to cancers of the digestive tract whereas in our study we studied the effect of Alcohol intake on buccal epithelial cells and showed an increased Comet Tail length by using the novel technique of Comet Assay indicating the risk of development of oral cancer. Our study is one of the fewer studies to demonstrate DNA damage due to Alcohol use in buccal epithelial cells ,earlier, Singh et al. [19] conducted an experiment which was the first one to demonstrate induction of DNA single-strand breaks after the consumption of Alcohol, but in rat brain cells and not buccal epithelial cells.

\section{Conclusion}

The present study demonstrates a considerable amount of DNA damage in buccal epithelial cells of users of alcohol by using the novel technique of Comet Assay which leads to the development of oral cancer and thus the confirmation of consumption of alcohol as an etiologic agent in the development and progression of oral carcinomas. This study also confirms that Comet Assay can be a successful and pre-diagnostic technique in the early detection of oral cancers among users of alcoholic beverages.

\section{References}

1. Blasiak J, Trzeciak A, Panas ME, Drzewoski J, Wojewodzka M (2000) In vitro genotoxicity of ethanol and acetaldehyde in human lymphocytes and the gastrointestinal tract mucosa cells. Toxicology in vitro 14(4): 287-295.

2. Tillonen J, Homann N, Rautio M, Somer JH, Salaspuro M (1999) Role of yeasts in the salivary acetaldehyde production from ethanol among risk groups for ethanol-associated oral cavity cancer. Alcohol Clinical and Experimental Research 23(8): 1409-1415

3. Seitz HK, Stickel F (2007) Molecular mechanisms of alcohol-mediated carcinogenesis. Nature Reviews Cancer 7(8): 599-612.

4. Mansouri A, Gaou I, de Kerguenec C, Amsellem S, Haouzi D, et al. (1999) An alcoholic binge causes massive degradation of hepatic mitochondrial DNA in mice. Gastroenterology 117(1): 181-190.
5. Navasumrit P, Ward TH, Dodd NJ, O'Connor PJ (2000) Ethanolinduced free radicals and hepatic DNA strand breaks are prevented in vivo by antioxidants: Effects of acute and chronic ethanol exposure. Carcinogenesis 21(1): 93-99.

6. Brooks PJ (1997) DNA damage, DNA repair, and alcohol toxicity-a review. Alcohol Clinical and Experimental Research 21(6): 1073-1082.

7. Navasumrit P, Ward TH, O’Connor PJ, Nair J, Frank N, et al. (2001) Ethanol enhances the formation of endogenously and exogenously derived adducts in rat hepatic DNA. Mutat Res 479(1): 81-94.

8. Singh NP, Lai H, Khan A (1995) Ethanol-induced single-strand DNA breaks in rat brain cells. Mutat Res 345(3): 191-196.

9. Rohatgi N, Kaur J, Srivastava A, Ralhan R (2005) Smokeless tobacco (khaini) extracts modulate gene expression in epithelial cell culture from an oral hyperplasia. Oral oncology 41(8): 806-820.

10. Giovino GA, Mirza SA, Samet JM, Gupta PC, Jarvis MJ, et al. (2012) Tobacco use in 3 billion individuals from 16 countries: an analysis of nationally representative cross-sectional household surveys. The Lancet 380: 668-679.

11. Stitch HF, Anders F (1989) The involvement of reactive oxygen species in oral cancer of betel quid-tobacco chewers. Mutation Research 214: 47-61.

12. Kido R, Sato I, Tsuda S (2006) Detection of in vivo DNA damage induced by ethanol in multiple organs of pregnant mice using the alkaline single cell gel electrophoresis (Comet) assay. J vet med sci 68(1): 41-47.

13. Guo L, Yang JY, Wu CF (2008) Oxidative DNA damage induced by ethanol in mouse peripheral leucocytes. Basic clin pharmacol toxicol 103(3): 222-227.

14. Collins AR (2002) The comet assay. Principles, applications, and limitations. Methods Mol Biol 203: 163-177.

15. Wong VWC, Szeto YT, Collins AR, Benzie IFF (2005) The comet assay: A biomonitoring tool for nutraceutical research. Curr Top Nutra Res 3: $1-14$.

16. Tice RR (1995) The single cell gel/comet assay: A microgel electrophoretic technique for the detection of DNA damage and repair in individual cells. In Phillips DH and Venitt S eds. Environmental mutagenesis. Oxford, BIOS Scientific pp. 315-339.

17. Garro AJ, Gordon BH, Lieber CS (1992) Alcohol abuse: Carcinogenic effects and fetal alcohol syndrome. Med Nutr Compli Alcohol pp. 459493.

18. Seitz HK, Stickel F (2010) Acetaldehyde as an underestimated risk factor for cancer development: Role of genetics in ethanol metabolism. Genes nutr 5(2): 121-128.

19. Longnecker MP (1996) Alcohol consumption and risk of cancer in humans: An overview. Alcohol 12(2): 87-96.

20. Watson RR, Odeleye OE, Eskelson CD, Mufti SI (1992) Alcohol stimulation of lipid peroxidation and esophageal tumor growth in mice immunocompromised by retrovirus infection. Alcohol 9(6): 495-500.

21. Lee CH, Wu DC, Lee JM, Wu IC, Goan YG, et al. (2007) Carcinogenetic impact of alcohol intake on squamous cell carcinoma risk of the oesophagus in relation to tobacco smoking. Eur j cancer 43(7): 11881199.

22. Brunnemann KD, Qi J, Hoffmann D (2001) Aging of oral moist snuff and the yields of Tobacco-Specific N-Nitrosamines (TSNA). Progress report prepared for the Massachusetts Tobacco Control Programme.

23. Kotova N, Vare D, Schultz N, Meesters GD, Stępnik M, et al. (2012) Genotoxicity of alcohol is linked to DNA replication-associated damage and homologous recombination repair. Carcinogenesis 34(2): 325-330. 
ISSN: 2574-1241

DOI: 10.26717/BJSTR.2019.20.003524

Sarim Ahmad. Biomed J Sci \& Tech Res

(c) (P) This work is licensed under Creative

Submission Link: https://biomedres.us/submit-manuscript.php

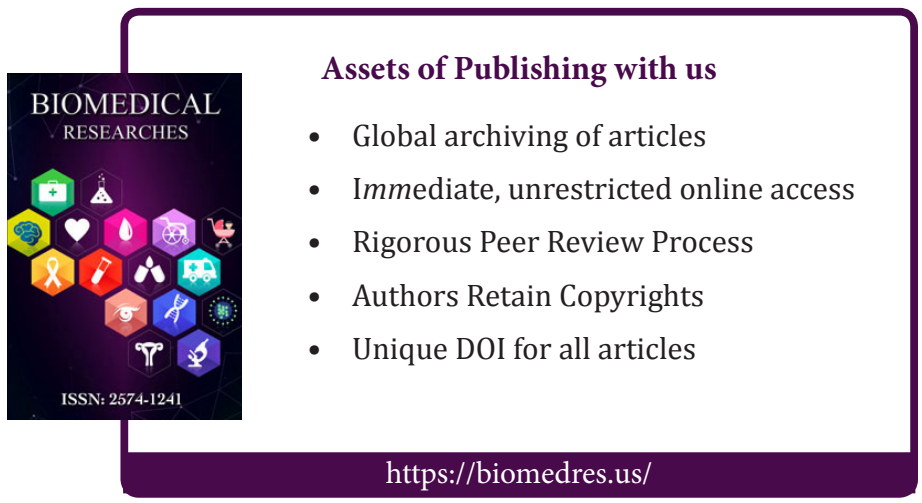

